\title{
HYDROGEOLOGIC CHARACTERIZATION OF THE COLDWATER SPRING RECHARGE AREA, CALHOUN COUNTY, ALABAMA
}

By Robert E. Kidd

U.S. GEOLOGICAL SURVEY

Open-File Report 01-300

Prepared in cooperation with the CITY OF ANNISTON

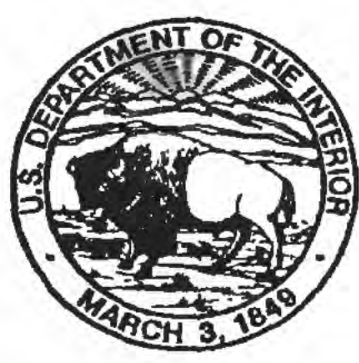

Montgomery, Alabama 2001 
U.S. DEPARTMENT OF THE INTERIOR

GALE A. NORTON, Secretary

U.S. GEOLOGICAL SURVEY

CHARLES G. GROAT, Director

For additional information, contact:

District Chief

U.S. Geological Survey

2350 Fairlane Drive, Suite 120

Montgomery, AL 36116
Copies of this report can be purchased from:

U.S. Geological Survey

Information Services

Box 25286, Federal Center

Denver, CO 80225 


\section{CONTENTS}

Abstract. . . . . 1

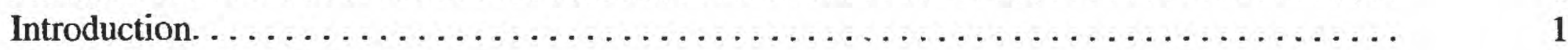

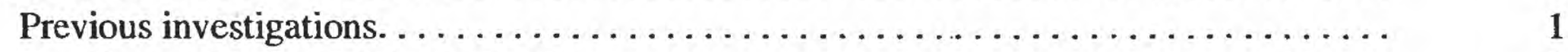

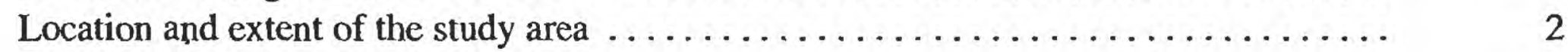

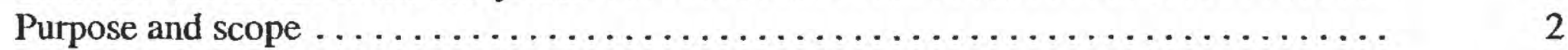

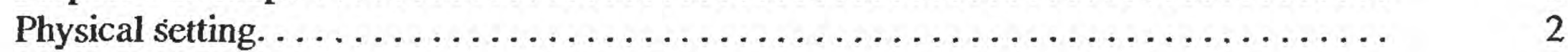

Acknowledgments . . . . . . . . . . . . . .

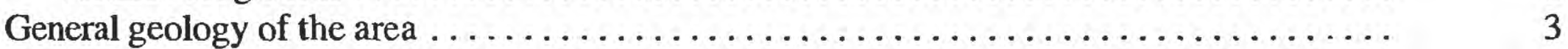

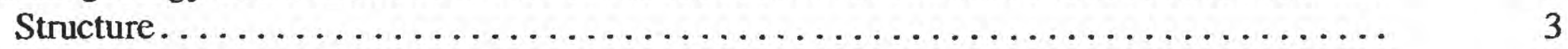

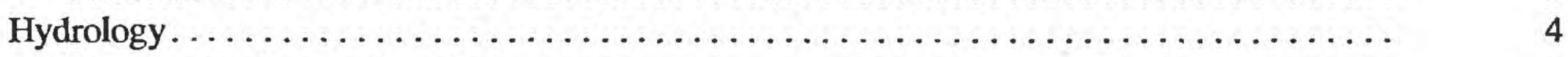

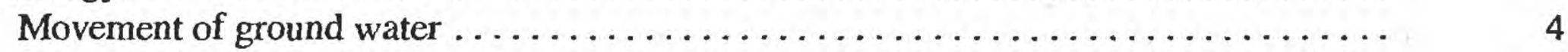

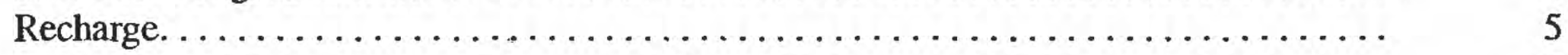

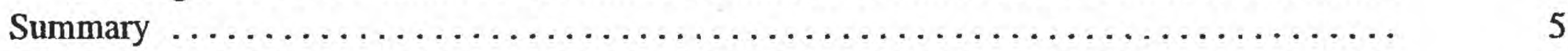

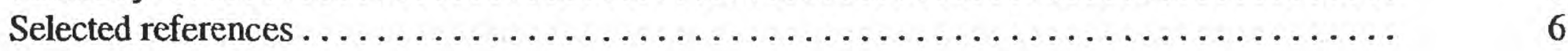

FIGURES (all figures placed in back of report)

1. Map showing location of the study area in Calhoun County, Alabama ........... 9

2. Generalized surface geology of the study area $\ldots \ldots \ldots \ldots \ldots \ldots \ldots \ldots \ldots \ldots \ldots \ldots$

3. Generalized subsurface section from $A$ to $A^{\prime} \ldots \ldots \ldots \ldots \ldots \ldots \ldots \ldots \ldots \ldots \ldots \ldots \ldots \ldots \ldots$

4. Conceptual ground-water flow system in the vicinity of Coldwater Spring, Calhoun County, Alabama. 
CONVERSION FACTORS

\begin{tabular}{rcl}
\hline Multiply & By & To.obtain \\
\hline inch (in.) & 25.4 & millimeter \\
foot (ft) & .3048 & meter \\
mile (mi) & 1.609 & kilometer \\
million gallons per day & .04381 & cubic meter per second \\
$($ Mgal/d) & & degree Celsius $\left({ }^{\circ} \mathrm{C}\right)$ \\
degree Fahrenheit $\left({ }^{\circ} \mathrm{F}\right)$ & ${ }^{\circ} \mathrm{C}=5 / 9 \times\left({ }^{\circ} \mathrm{F}-32\right)$ & \\
\hline
\end{tabular}




\title{
HYDROGEOLOGIC CHARACTERIZATION OF THE COLDWATER SPRING RECHARGE AREA, CALHOUN COUNTY, ALABAMA
}

\author{
By Robert E. Kidd
}

\begin{abstract}
The complex ground-water flow in the Coldwater Spring aquifer system is the result of complicated geologic structures, porous media flow within the shallow unconsolidated zone, conduit flow in karst bedrock aquifers, and discontinuities in hydrogeologic units caused by faulting. Recharge water in the unconsolidated zone percolates slowly to the underlying bedrock aquifer. The bedrock aquifer includes fractured zones in the Chilhowee Group and solution features in the Shady Dolomite, Conasauga Formation, Knox Group, and Newala and Little Oak Limestones.
\end{abstract}

Ground-water movement in the shallow unconsolidated zone roughly follows the topographic surface as it moves deeper into the ground-water system. Ground water flowing south through the bedrock aquifers is blocked by less permeable rocks in the area of the Jacksonville Fault; and possibly moves south and west along the fault to discharge at Coldwater Spring. The recharge area for Coldwater Spring encompasses the recharge areas of the shallow unconsolidated zone and the bedrock aquifers.

\section{INTRODUCTION}

Coldwater Spring is the primary source of water supply for the city of Anniston, Anniston Army Depot, and several smaller towns and communities in the Anniston area, Calhoun County, Alabama (fig. 1) (Anniston Water Works and Sewer Board, 2000). An average daily use supplied by Coldwater Spring in 1999 was 12.6 $\mathrm{Mgal} / \mathrm{d}$ (million gallons per day). The peak daily usage in 1999 was $17.7 \mathrm{Mgal} / \mathrm{d}$. The spring is one of the largest in Alabama, having an average discharge of $31.2 \mathrm{Mgal} / \mathrm{d}$.

The 1996 Amendments to the Safe Drinking Water Act (SDWA) of 1974 requires management of public supply wells to establish well head protection areas (WHPAs) within which potential contamination sources are identified. These WHPAs are defined as the surface or subsurface area that surrounds a public drinking water well or wellfield where contaminants are "reasonably likely" to move toward and reach the well or wellfield over a given period of time. The Alabama Department of Environmental Management (ADEM) approved methods and procedures for the delineation of WHPAs (ADEM, 1991). The methods include defining the local geologic (stratigraphy, structure, lithology) and hydrologic (aquifer characteristics, ground-water flow direction, hydraulic gradients, and flow divides/boundaries) conditions controlling the occurrence and movement of ground water relative to each well or wellfield. Procedures for delineating WHPAs are described in Federal and State technical guidance manuals (USEPA, 1991; ADEM, 1991). Based on these manuals, the preferred methods for delineation of the hydrogeologic flow boundaries for fractured-rock aquifer systems are by a combination of (1) flowsystem mapping, hydrogeologic mapping and geochemical and isotopic characterization of the ground-water system or (2) of flow-system mapping and numerical modeling.

This report was cooperatively supported by the city of Anniston and the U.S. Geological Survey and provides information on the hydrogeology and recharge area of the Coldwater Spring aquifer system. This information will be used to provide a basis for additional studies in the Anniston area.

\section{Previous Investigations}

This report is based on findings of previous investigations in the Calhoun County area and other areas of karst hydrology. The complex geology and hydrology of the Coldwater Spring area have been described by many authors. Investigations of the geology of the general area 
began in the 19th century (McCalley, 1897). Reports published before 1900 by the Geological Survey of Alabama described mineral deposits of the region. Smith (1907) conducted a study of ground-water resources of Alabama. Adams and others (1926) provided the descriptive base of most geologic studies in Alabama since its publication.

Well inventories and discussions of the water resources of the area were presented by Johnston (1933), Warman and others (1960), Warman and Causey (1962), and Moser and DeJarnette (1992). Scott and others (1987) presented an estimate of the recharge area for Coldwater Spring based on data from 140 wells and springs. Robinson and others (1997) include the study area in estimates of ground-water discharge.

The stratigraphy and structural geology associated have been described by McCalley (1897), Butts (1926), Warman and others (1960), Warman and Causey (1962), Cloud (1966), Denson and Waage (1966), Drahovzal and others (1974), Drahovzal and Thomas (1976), Kidd and Neathery (1976), Bearce (1978), Mack (1980), Thomas and Neathery $(1980,1982)$, and Osborne and Szabo (1984).

Numerous studies on the hydrogeology of the area have been made by various contractors for the U.S. Army Anniston Army Depot (ANAD). ANAD is located about 10 miles west of the city of Anniston (fig. 1). These investigations include geophysical surveys (Thompson and others, 1999), dye-tracer tests (Science Application International Corp., 1998), and hydrogeologic characterization of the Jacksonville thrust fault (Science Application International Corp., 1999).

\section{Location and Extent of the Study Area}

The Coldwater Spring aquifer system is in eastern Calhoun County (fig. 1). The area studied to determine the extent of the aquifer system extends from the southern boundary of the county, northward and northeastward through Anniston and Jacksonville to Piedmont, and includes most of central and eastern Calhoun County. The extent of the study area is shown on figure 1 .

\section{Purpose and Scope}

The purpose of this report is to provide a hydrogeologic characterization of the Coldwater
Spring aquifer system using published literature on hydrology and geology.

\section{Physical Setting}

The study area is in the Alabama Valley and Ridge section of the Valley and Ridge physiographic province (Fenneman, 1938). The topography of the study area is characterized by flat to gently-rolling northeastward trending valleys paralleled by ridges and mountains. Maximum local relief in the area is about 1,500 feet. The highest points are at an altitude of about 2,100 feet above sea level along the crest of Choccolocco Mountain. The surface altitude of Coldwater Spring is about 590 feet above sea level.

The study area is drained by tributaries of the Coosa River (Harkins, 1965). Eastern and southern parts of the area are drained southeastward by Choccolocco Creek; the west central part is drained westward by Cane and Tallasseehatchee Creek; and the northern part is drained by Terrapin Creek. Numerous springs sustain the dry-weather flow of the streams.

Calhoun County has a moist temperate climate. The mean annual precipitation of about 53 inches is fairly well distributed throughout the year. The heaviest rainfall normally occurs in winter and spring, March being the wettest month. Thunderstorms generally are most frequent in the summer, but may occur in any month of the year. The driest month usually is October.

The average annual temperature at Anniston is about $63^{\circ} \mathrm{F}$. Temperature extremes recorded by the National Weather Service are $-5^{\circ} \mathrm{F}$ and $106^{\circ} \mathrm{F}$ (National Climatic Data Center, 1999).

\section{Acknowledgments}

Acknowledgment is made to the residents and businesses of Calhoun County who furnished information on wells and springs and other significant data. Mr. James Miller, Waterworks manager for the city of Anniston and Ms. Susan Abston, Directorate of Risk Management for Anniston Army Depot. The author also expresses appreciation to Mr. Riley Cobb, U.S. Geological Survey (Ret.) for his invaluable assistance in the location of wells and springs. 


\section{GENERAL GEOLOGY OF THE AREA}

The stratigraphic and structural relations of the rocks throughout the Coldwater Spring study area are typical of the Valley and Ridge physiographic province. Sedimentary and slightly metamorphosed sedimentary rocks of Paleozoic age underlie the area. These rocks have been complexly folded and faulted into northeastwardtrending synclines and anticlines complicated by thrust faults that generally strike northeast and dip southeast. Fluvial deposits of Tertiary age overlie Paleozoic formations in some parts of the study area (fig. 2).

Consolidated rocks in the study area consists of Cambrian to Ordovician age clastic and carbonate rocks composed of sandstones, shales (mudstones), cherty limestones, dolomites, and quartzites (Osborne and Szabo, 1984). Cambrian rocks, from oldest to youngest, include the Chilhowee Group, Shady Dolomite, Rome Formation, Conasauga Formation, and the lower part of the Knox Group. The upper part of the Knox Group, and the Newala and Little Oak Limestone are Ordovician in age (Osborne and Szabo, 1984).

The Chilhowee Group includes the Weisner and Wilson Ridge Formations. The Chilhowee Group consists of about 1,100 feet of quartzite, sandstone, conglomerate, shale, and mudstone (Scott and others, 1987). The Shady Dolomite overlies the Chilhowee Group and consists of 500 to 1,000 feet of sandy dolostone and dolomitic limestone. Much of Anniston is underlain by the Shady Dolomite (Warman and Causey, 1962). The Rome Formation overlies the Shady Dolomite and consists of about 1,000 feet of mudstone, shaley mudstone, and shale (Scott and others, 1987). Northeast of the town of Weaver, the Rome is a ridge-forming unit whereas southwest of Weaver it typically forms small knolls and valleys (Osborne and Szabo, 1984). The Conasauga Formation overlies the Rome Formation and consists of 100 to 500 feet of mudstone and shale with interbeds of limestone and siltstone. Throughout the outcrop area, the Conasauga is covered by as much as 100 feet of dark-red residual clay and chert boulders (Warman and Causey, 1962). The Knox Group of Cambrian and Ordovician ages overlie the Conasauga Formation and has a thickness estimated to be about 2,000 feet (Osborne and Szabo, 1984).

The Newala and Little Oak Limestones of Ordovician age overlie the Knox Group. These two formations were mapped as a unit by Osborne and Szabo (1984). The Newala Limestone consists of light to medium gray, thick-bedded micritic limestone, dolomitic limestone, and dolomite. The Little Oak Limestone consists of medium to dark gray, thin to thick-bedded argillaceous fossiliferous limestone. The combined thickness of these units is about 300 to 400 feet. The Athens Shale of Late Ordovician age consists of dark gray to black, shale and shaley mudstone. The Athens is about 200 to 300 feet thick in the study area (Scott and others, 1987).

Carbonate rocks in the study area are deeply weathered, and a mantle of residuum (in-place decomposed bedrock) has developed on the outcrops. The residuum, which consists of residual clay and chert boulders and fragments, generally ranges in thickness from 30 to 100 feet. Sinkholes and depressions have developed on the surface of the residuum in some areas, particularly where the Knox Group crops out (Scott and others, 1987). The residuum appears to be moderately permeable and highly permeable where sinkholes and depressions have formed (Schalla and others, 1984).

\section{Structure}

Paleozoic rock formations in the study area have been extensively folded and thrust faulted by northwestward-directed tectonic stresses (SAIC, 1999). As a result of this deformation, geologic structures, including fault axes, fault traces and lithologic boundaries are predominantly oriented in a northeast-southwest direction. Northwestward transport of the Paleozoic rock sequence along thrust faults has resulted in the overlapped stacking of large slabs of rock referred to as thrust sheets (SAIC, 1999).

Smaller faults may splay off the larger basal fault within an individual thrust sheet, resulting in multiple stacking and repetition of rock units (Osborne and Szabo, 1984). In the study area, geologic contacts are generally oriented parallel to mapped faults, and repetition of lithologic units in vertical sequences is common. 
Major thrust faults in the study area include the Pell City fault and the Jacksonville thrust fault (figs. 2 and 3). The Pell City fault is a regionalscale feature along which Cambrian and Ordovician rocks have been thrust over younger Mississippian-Pennsylvanian rocks. The smaller Jacksonville thrust fault is a northeast-southwest trending, fault that is a major splay of the Pell City fault (Osborne and Szabo, 1984). Earlier reports (Osborne and Szabo, 1984; Scott and others, 1987) indicate that the Jacksonville Fault trends northeastward from the vicinity of Bynum and Coldwater Spring through Anniston to Piedmont in the northeastern corner of Calhoun County. Recent geologic investigation extends the trace of the fault southwestward into Talladega County (Thompson and others, 1999).

Coldwater and Choccolocco Mountains are minor splays off the Jacksonville Fault that have resulted in complex, plunging anticlinal structures (fig. 3). Fault splays are also responsible for repetition of the Chilhowee Group in Coldwater Mountain (Osborne and Szabo, 1984). Northeast of Coldwater Mountain increases in displacement and other changes in the structural style of the Jacksonville Fault have been attributed in part to cross-strike structural features or discontinuities (Drahovzal and Neathery, 1972). Osborne and Szabo (1984) report the presence of well defined lineaments on Coldwater Mountain that show alignment of two large collapse structures on the southwest end of Coldwater Mountain and Coldwater Spring.

Structural features studied at ANAD are indicative of structural features throughout the study area. The U.S. Army Corps of Engineers Topographic Engineering Center (1998) used historical aerial photographs to map extensive fractures in the Knox Group under and adjacent to ANAD. Two dominant joint sets trendings N30E and N60W were mapped at ANAD (Technos, Inc., 1985).

\section{HYDROLOGY}

The complex ground-water flow in the vicinity of Coldwater Spring is the result of complicated geologic structures, shallow porous media in the unconsolidated zone, conduit flow in the karst bedrock, and discontinuities of hydrogeologic units caused by faulting, jointing, and fracturing (SAIC, 1999). Previous investigations have indicated that two variably interactive ground-water zones are present: an unconsolidated, weathered zone and a bedrock zone (Fauss and others, 1987; Planert and Pritchett, 1989; Jacobs Engineering, 1994; SAIC, 1998, 1999).

The unconsolidated zone generally is a mantle of residuum which is the product of the weathering of the underlying parent material. The shallow residuum often is a zone of low permeability allowing water to occur under perched or watertable conditions. The permeability of the residuum is typically greatest near the residuum-bedrock contact (SAIC, 1999). Thick residuum stores recharge water and slowly releases the water to the bedrock aquifer or to springs and streams.

The bedrock aquifers include fractured zones in the Chilhowee Group and solution features in the Shady Dolomite, Conasauga Formation, Knox Group, and Newala and Little Oak Limestones. In areas where faulting has not displaced formations, aquifers in each formation are probably separated to some extent by shale, clay, and confining beds. Movement along the Jacksonville Fault and other associated faults has juxtaposed the aquifers so that all are hydraulically interconnected (Scott and others, 1987) (fig. 2).

The Coldwater Spring aquifer system is comprised of the karst bedrock aquifer and the overlying residuum. Recharge from precipitation moves through the residuum to recharge the underlying bedrock aquifer and to discharge points in springs and streams (fig. 4).

\section{Movement of Ground Water}

The movement of ground water in the study area is controlled by topography and the permeability and geologic structure of the residuum and bedrock (Scott and others, 1987). Warman and Causey (1962) determined that in Calhoun County the general movement of ground water was to the south and west, based on water levels measured throughout the county. Scott and others (1987) presented a potentiometric map of the shallow flow system that shows the potentiometric surface of the system roughly follows the topographic surface where the potentiometric highs coincide with the mountains 
and ridges in the area and the potentiometric lows coincide with the axes of the valleys. Therefore, ground-water movement in the shallow system is from mountains and ridges to valleys.

Ground water in deeper carbonate rocks with interconnected karst features can move over great distances in less time than the shallow groundwater system. SAIC (1999) determined that the general movement of ground water in both the unconsolidated and bedrock aquifers was toward the south and west. Ground water in the carbonate rocks moving to the south is blocked by less permeable rocks in the area of the Jacksonville fault. Subsequently, ground water probably moves south and west along the Jacksonville fault, joining ground water from distant sources moving parallel to the fault at depth. The ground water discharges under pressure at Coldwater Spring (Warman and Causey, 1962; Fauss and others, 1987). Warman and Causey (1961) also noted that all large, lowvariability springs in Calhoun County are near the trace of thrust faults.

Recent studies by SAIC (1998) at ANAD included tracer studies that show the Knox Group has small, solutionally enlarged voids and conduits, however, the ground-water flow appears to be laminar rather than turbulent. The tracer studies also showed no detection of injected dyes at locations outside of ANAD, including Coldwater Spring.

\section{Recharge Area}

Scott and others (1987) estimated the recharge area of Coldwater Spring to be about 90 square miles. The low variability of discharge of Coldwater Spring and the absence of turbidity in water discharging from the spring to support their conclusions that the spring discharges from a deep flow system with a remote source.

The recharge area for Coldwater Spring includes the recharge area for the shallow unconsolidated zone that roughly follows topography, and the recharge area for the bedrock aquifers that is structure controlled. The recharge area probably includes the area northwest of the crests of Coldwater and Choccolocco Mountains along the Jacksonville fault. Data are insufficient to determine the northwest and northeast boundaries of the recharge area.

\section{SUMMARY}

Coldwater Spring is the primary source of water supply for the city of Anniston, Anniston Ordinance Depot, and several smaller towns and communities in the Anniston area, Calhoun County, Alabama. The spring is one of the largest in Alabama.

Management of public supply wells are required to establish well head protection areas within which potential contamination sources are managed. The Alabama Department of Environmental Management established approved methods and procedures for the delineation of well head protection areas.

The complex ground-water flow in the Coldwater Spring aquifer system is the result of complicated geologic structures, shallow flow in the unconsolidated zone, conduit flow in karst bedrock aquifer, and discontinuities of hydrogeologic units caused by faulting, jointing, and fracturing. Ground-water movement in the shallow system is from mountains and ridges to valleys. Ground water in deeper carbonate rocks flows south until it is blocked by less permeable rocks in the area of the Jacksonville fault (fig. 3). Subsequently, ground water probably moves south and west along the Jacksonville fault, joining ground water from distant sources moving parallel to the fault at depth.

The recharge area for Coldwater Spring includes the recharge area for the shallow unconsolidated zone that roughly follows topography and the recharge area for the bedrock aquifers that is structure controlled. The recharge area probably includes the area northwest of the crests of Coldwater and Choccolocco Mountains along the Jacksonville fault. Data are insufficient to determine the northwest and northeast boundaries of the recharge area. 


\section{SELECTED REFERENCES}

Adams, G.I., Butts, C., Stevenson, L.W., and Cooke, C.W., 1926, Geology of Alabama: Geological Survey of Alabama Special Report $14,312 \mathrm{p}$.

Alabama Department of Environmental Management, 1982, Regulations governing public water supplies: Alabama Department of Environmental Management open-file report, $100 \mathrm{p}$.

1989, Administrative Code: Alabama Department of Environmental Management Adminisrative Code R. $335-7$, January 4, 1989.

1991, Alabama wellhead protection program:

Alabama Department of Environmental Management, Montgomery, $71 \mathrm{p}$.

Anniston Water Works and Sewer Board, 2000, Monthly reports (Jan.-Dec. 2000).

Atkins, J.B., and Pearman, J.L., 1994, Low flow and flow-duration characteristics of Alabama streams: U.S. Geological Survey WaterResources Investigations Report 93-4186, 264 p.

Bearce, D.N., 1978, Structure of the eastern Coosa valley, Alabama: American Journal Science, v. 278 , p. $461-476$.

Bingham, R.H., 1979, Low-flow characteristics of Alabama streams: Geological Survey of Alabama Bulletin 117, 39 p.

Butts, Charles, 1926, The Paleozoic Rocks, in Adams, G.I., Butts, Charles, Stephenson, L.W., and Cooke, C.W., Geology of Alabama: Geological Survey of Alabama Special Report 14 , p. $40-230$.

Chandler, R.V., and Moore, J.D., 1987, Springs in Alabama: Geological Survey of Alabama Circular 134, 95 p.

Cloud, P.E., Jr., 1966, Bauxite deposits of the Anniston, Fort Payne, and Ashville areas, northeast Alabama: U.S. Geological Survey Bulletin 1199-O, 35 p.

Denson, N.M., and Waage, K.M., 1966, Some bauxite and clay deposits in northeastern Alabama: U.S. Geological Survey Bulletin 1199-P, 27 p.
Drahovzal, J.A., and Neathery, T.L., 1971, Middle and Upper Ordovician stratigraphy of the Alabama Appalachians, in Drahovzal, J.A., and Neathery, T.L., eds., The Middle and Upper Ordovician of the Alabama Appalachians: Alabama Geological Society Guidebook, 9th Annual Field Trip, p. 1-62.

1972, The structural significance of multispectral Apolla 9 photographs to Appalachian geotectonics [abstract]: International Geological Congress, Montreal, 1972, sec. 9, p. 3 .

Drahovzal, J.A., Neathery, T.L., and Wielchowsky, C.C., 1974, Significance of selected lineaments in Alabama: Earth Resources Technology Satellite-1 Symposium, 3rd, Technical Presentations, v. 1, sec. A, paper G-24, SP-351, p. 897-918.

Drahovzal, J.A., and Thomas, W.A., 1976, Crossstrike structural discontinuities in the Appalachians of Alabama: Geological Society of American Abstracts with Programs, v. 8, p. 165.

Fauss, L.M., Mata, L., and Stout, K.K., 1987, Photogeologic study of potential ground water pollution pathways between Anniston Army Depot and Coldwater Spring, Alabama: Environmental Photographic Interpretation Center, Bionetics Corp., project report for the U.S. Army Toxic and Hazardous Materials Agency, $20 \mathrm{p}$.

Fenneman, N.M., 1938, Physiography of eastern United States: McGraw-Hill, New York. 714 p.

Harkins, J.R., 1965, Surface water resources of Calhoun County, Alabama: Geological Survey of Alabama Circular 33, 75 p.

Harris, L.D., 1976, Thin-skinned tectonics and potential hydrocarbon traps illustrated by a seismic profile in the Valley and Ridge province of Tennessee: U.S. Geological Survey Journal Research, v. 4, no. 4, p. 379386.

Harris, L.D., and Milici, R.C., 1977, Characteristics of thin-skinned type of deformation in the southern Appalachians, and potential hydrocarbon traps: U.S. Geological Survey Professional Paper 1018, 40 p. 
Hayes, E.C., 1978, 7-day low flows and flow duration of Alabama streams through 1973: Geological Survey of Alabama Bulletin 113, $163 \mathrm{p}$.

Jacobs Engineering Group, 1994, Draft Final Phase I Remedial Investigation Report, Southeast Industrial Area, Anniston Army Depot, Alabama, project report for the U.S. Army Anniston Army Depot.

Jacobeen, Frank, Jr., and Kanes, W.H., 1974, Structure of Broadtop synclinorium and its implications for Appalachian structural style: American Association of Petroleum Geologists Bulletin, v. 58 , no. 3, p. 366-375.

Johnston, W.D., Jr., 1933, Ground water in the Paleozoic rocks of northern Alabama: Geological Survey of Alabama Special Report 16, pt. 1, 414 p., p. 2, 48 well and spring tables.

Kidd, J.T., and Neathery, T.L., 1976, Correlation between Cambrian rocks of the southern Appalachian geosyncline and the Interior Low Plateaus: Geology, v. 4, p. 767-769.

Mack, G.H., 1980, Stratigraphy and depositional environments of the Chilhowee Group (Cambrian) in Georgia and Alabama: American Journal of Science, v. 280, p. 497517.

McCalley, Henry, 1897, Report on the valley regions of Alabama (Paleozoic strata); pt. 2, The Coosa Valley region: Alabama Geological Survey Special Report 9, 862 p.

Meinzer, O.E., 1923, Outline of ground-water hydrology, with definitions: U.S. Geological Survey Water-Supply Paper 494, 71 p.

Moser, P.H., and DeJarnette, S.S., 1992, Groundwater availability in Calhoun County, Alabama: Geological Survey of Alabama Special Map 228, 115 p.

National Climatic Data Center, 1999, Climatological data Alabama 1999, v. 105, no. 01-12.

Osborne, W.E., and Szabo, M.W., 1984 Stratigraphy and structure of the Jacksonville Fault, Calhoun County, Alabama: Geological Survey of Alabama Circular 117, 30 p.

Planert, Michael, and Pritchett, J.L., Jr., 1989, Geohydrology and susceptibility of major aquifers to surface contamination in
Alabama-area 4: U.S. Geological Survey Water-Resources Investigations Report 88-4133, $31 \mathrm{p}$.

Raymond, D.E., and Copeland, C.W., 1983, Stratigraphic column of eastern Valley and Ridge northern segment, Calhoun County, southeastern Cherokee County, and southeastern Etowah County: Geological Survey of Alabama open-file report.

Robinson, J.L., Journey, C.A., and Atkins, J.B., 1997, Ground-water resources in the Coosa River basin in Georgia and Alabama-Subarea 6 of the Apalachicola-Chattahoochee-Flint and Alabama-Coosa-Tallapoosa River basins: U.S. Geological Survey Open-File Report 96-177, $53 \mathrm{p}$.

Schalla, Ronald, and others, 1984, Source identification, contaminant transport simulation, and remedial action analysis, Anniston Ordinance Depot, Anniston, Alabama: U.S. Department of Defense Report DRXTH-AS-CR-83265C by Battelle Project Management Division, Office of Hazardous Waste Management, Richland, Washington.

Science Applications International Corporation, 1998, Report of findings for the groundwater tracer test at the Anniston Army DepotSoutheast Industrial Area, Anniston, Alabama, $43 \mathrm{p}$.

1999, Work plan for phase one of the offpost remedial investigation: Hydrogeologic characterization of the Jacksonville Thrust Fault at Anniston Army Depot, Anniston, Alabama, $73 \mathrm{p}$.

Scott, J.C., Harris, W.F., and Cobb, R.H., 1987, Geohydrology and susceptibility of Coldwater Spring and Jacksonville fault areas to surface contamination in Calhoun County, Alabama: U.S. Geological Survey Water-Resources Investigations Report 87-4031, 20 p.

Shaw, C.E., 1973, Stratigraphy, structure, and tectonics of rocks adjacent to the Piedmont physiographic front in Talladega County, Alabama, in Carrington, T.J., ed., Talladega metamorphic front: Alabama Geological Society Guidebook, 11 th Annual Field Trip, p. 56-65. 
Smith, E.A., 1907, The underground water resources of Alabama: Geological Survey of Alabama Monograph 6, $388 \mathrm{p}$.

Technos, Inc., 1985, Investigation of possible Paleochannels at the Anniston Army Depot, Anniston, Alabama; Report for Environmental Science and Engineering, Inc., Gainesville, Florida, and the U.S. Army Toxic and Hazardous Materials Agency, Aberdeen Proving Ground, Maryland; Technos Project No. $85-183,39$ p.

Thomas, W.A., 1982 Stratigraphy and structure of the Appalachian fold and thrust belt in Alabama, in Thomas, W.A., and Neathery, T.L., eds., Appalachian thrust belt in Alabama: tectonics and sedimentation: Geological Society of America Guidebook, Field Trip no. 13, p. 55-66.

Thomas, W.A., and Drahovzal, J.A., 1973, Regional Paleozoic stratigraphy of Alabama, in Carrington, T.J., ed., Talladega metamorphic front: Alabama Geological Society Guidebook, 11th Annual Field Trip, p. 66-91.

1974a, Geology of the Coosa deformed belt, in Thomas, W.A., and Drahovzal, J.A., eds., The Coosa deformed belt in the Alabama Appalachians: Alabama Geological Society Guidebook, 12th Annual Field Trip, p. 45-75. 1974b, A field guide to the Coosa deformed belt, in Thomas, W.A., and Drahovzal, J.A., eds., The Coosa deformed belt in the Alabama Appalachians: Alabama Geological Society Guidebook, 12th Annual Field Trip, p. 1-43.

Thomas, W.A., and Neathery, T.L., 1980, Tectonic framework of the Appalachian orogen in Alabama, in Frey, R.W., ed., Excursions in southeastern geology, v. 11: American Geological Institute, p. 465-526.

1982, Appalachian thrust belt in Alabama, in Thomas, W.A., and Neathery, T.L., eds., Appalachian thrust belt in Alabama: tectonics and sedimentation: Geological Society of America Guidebook, Field Trip no. 13, p. 1-3.

Thomas, W.A., Tull, J.T., Neathery, T.L., Mack, G.H., and Ferrill, B.A., 1982, A field guide to the Appalachian thrust belt in Alabama, in Thomas, W.A., and Neathery T.L., eds.,
Appalachian thrust belt in Alabama: tectonics and sedimentation: Geological Society of America Guidebook, Field Trip no. 13, p. 540.

Thompson, M.D., Glennon, M.A., Benson, M.A., Miller, S.F., and Podar, C.A., 1999, Geophysical investigations, southeast investigations, southeast industrial area, Anniston Army Depot, Alabama: Argonne National Laboratory publication, $113 \mathrm{p}$.

U.S. Army Corps of Engineers, Topographic Engineering Center, 1998, Alexandria, Virginia, 1997/92 and 1937 Image Maps and Data.

U.S. Environmental Protection Agency, 1984, A ground-water protection strategy for the Environmental Protection Agency, 56 p. 1991, Delineation of wellhead protection areas in fractured rocks: U.S. Environmental Protection Agency, Office of Water, EPA/570/ 9-91-009, $144 \mathrm{p}$.

U.S. Geological Survey, 1977, Areas in which sinkholes have occurred or can occur in Calhoun, Jefferson, Shelby, St. Clair, and Talladega Counties, Alabama: U.S. Geological Survey unnumbered open-file report, 5 sheets.

Warman, J.C., and Causey, L.V., 1959, Ground water from springs in Calhoun County, Alabama (abstract): Geological Society of America Bulletin, v. 70, no. 12, pls. 2, p. 16941695.

1961, Relation of springs to thrust faults in Calhoun County, Alabama: Geological Survey of Alabama Reprint Series 3, p. 87-94.

1962, Geology and ground-water resources of Calhoun County, Alabama: Geological Survey of Alabama County Report 7, 77 p.

Warman, J.C. Causey, L.V., Burks, J.H., and Ziemond, H.W., 1960, Geology and groundwater resources of Calhoun County, Alabama-an interim report: Geological Survey of Alabama Information Series 17, $67 \mathrm{p}$. 


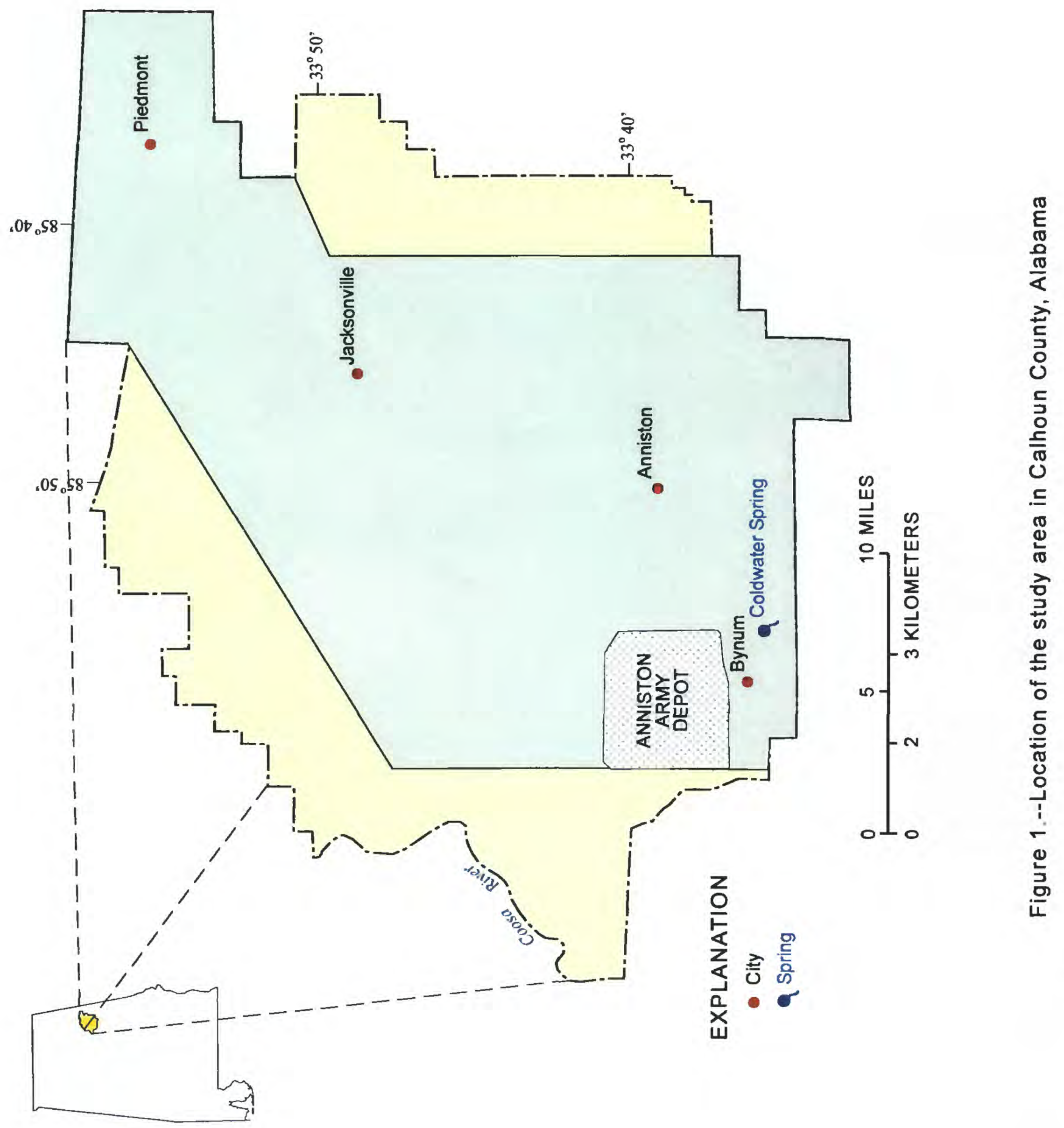




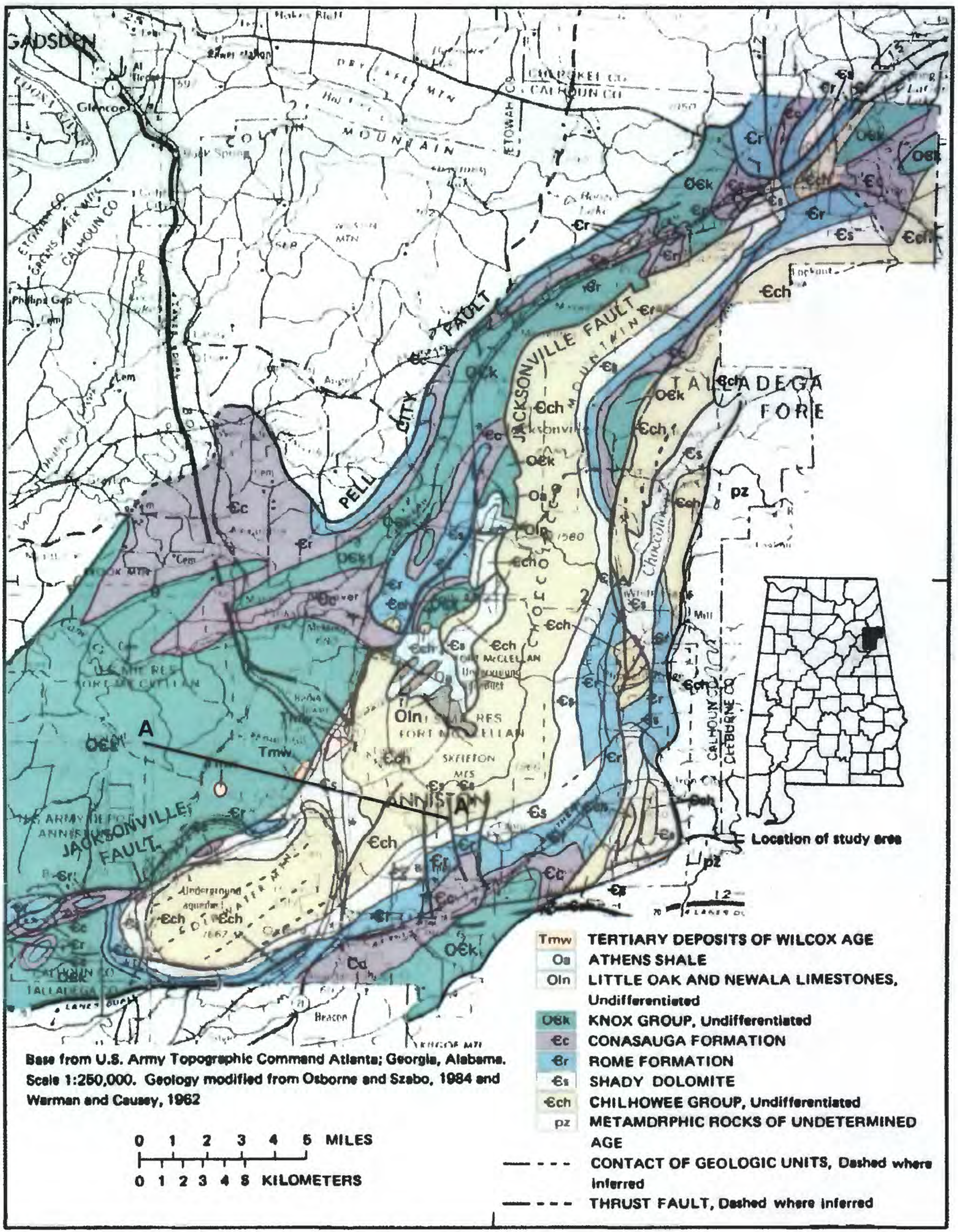

Figure 2.--Generalized geology of the area of study. 


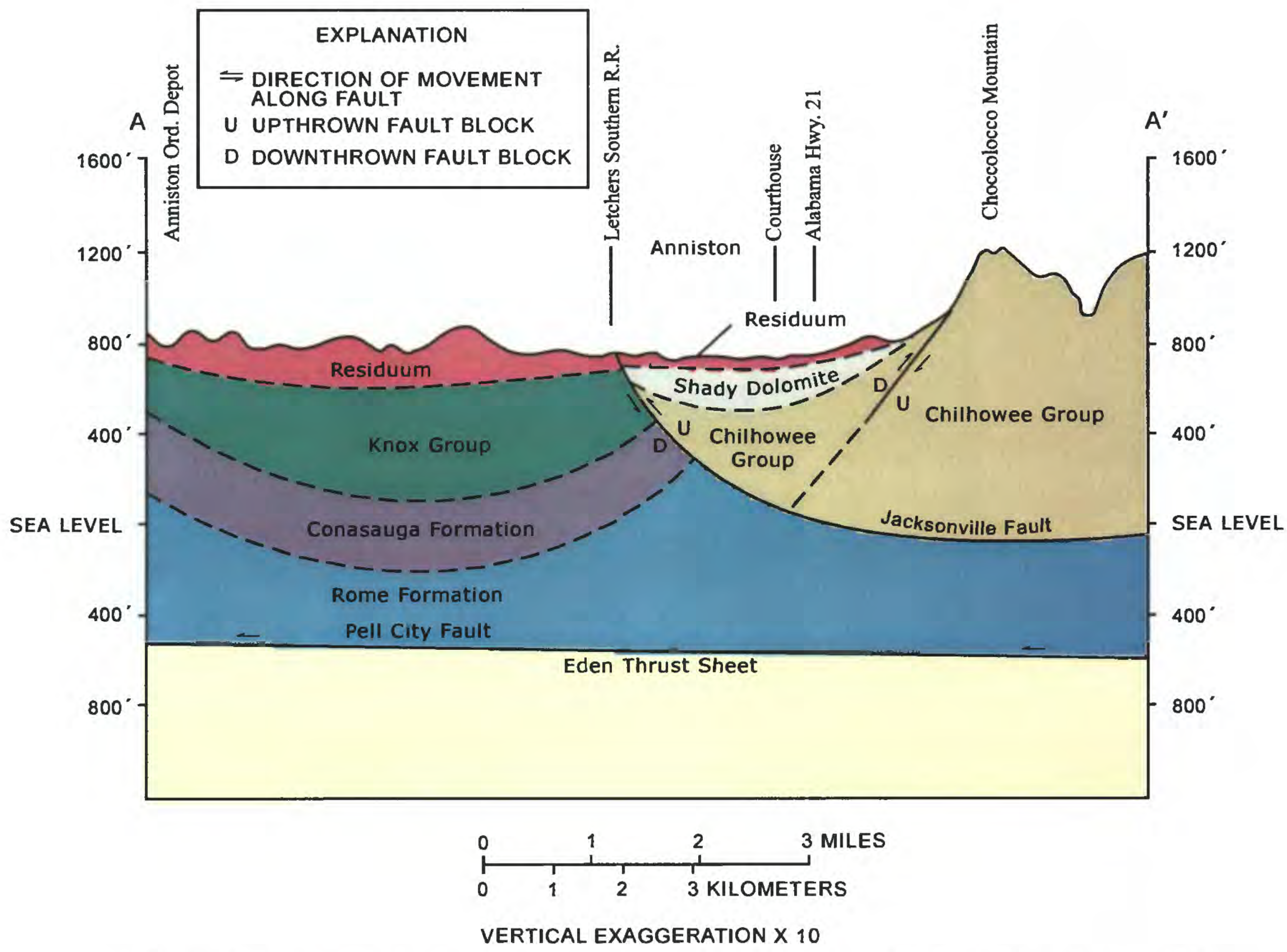

Figure 3.--Generalized subsurface section from $A$ to $A^{\prime}$. Line of section shows on figure 2. 


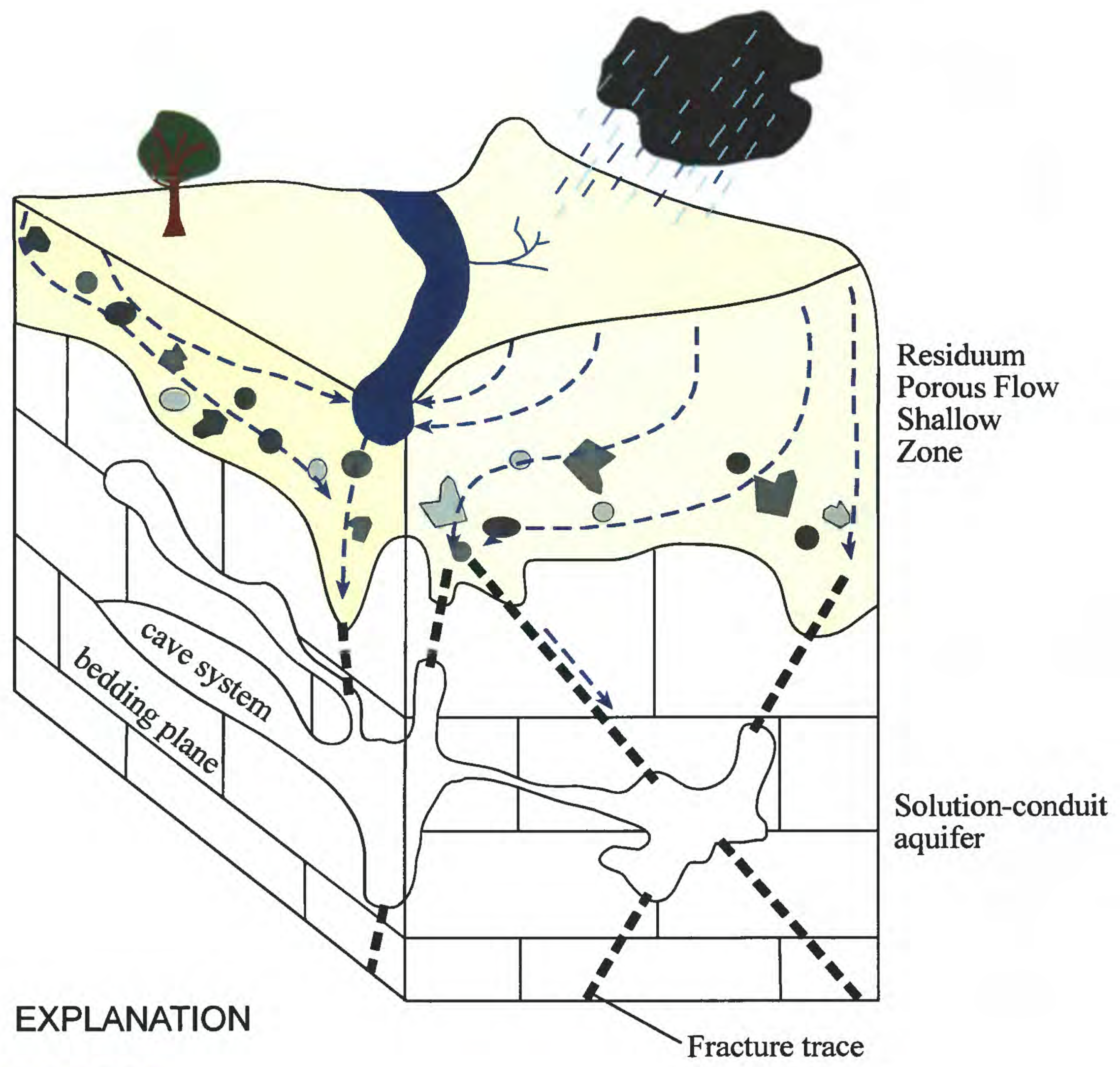

$----\longrightarrow$

Generalized direction of ground-water flow

Figure 4. - Conceptual ground-water flow system in the vicinity of Coldwater Spring, Calhoun County, Alabama 